\title{
Burial demography in the late Middle Kingdom: a social perspective*
}

\author{
Gianluca Miniaci
}

\begin{abstract}
The paper aims at analysing the social factors connected with the increase of sequential multiple burials around the first quarter of the Second Millennium BC in Egypt. In particular, in the late Middle Kingdom, the practice of multiple burials became more widespread across the whole country and it was more visible at all social levels, reaching also the uppermost levels of society and the royal court. Such a burial demography pattern can be linked with deeper transformations in the social organisation noticeable through iconographic, textual, linguistic, and archaeological evidence: an increase of plurality of people named/represented on stelae; a lexical deviation inside the vocabulary related to 'familial' groups (CT 146); the interruption in the archaeological record of the texts known as 'Letters to the Dead'; the introduction of an uncommon architectural feature in the eastern Delta (Avaris), the 'house of the dead'. The increase and spread on a preeminent scale of multiple burials drove a renegotiation of the role of the dead body within the burial assemblage. In the light of a changed burial demography, the tomb became the ideal memory container for supporting the identity of a more crowded household structure and dead bodies constituted the tangible mnemonic bridge to the past and social identity. Sequential multiple burials affected also temporality, and the passage of time increased the objectification of the body itself; therefore multiple bodies inside a grave may have influenced the selection of the range of objects to be placed in, as demonstrated by a consistent infiltration of the domestic sphere inside the funerary domain at the end of Twelfth Dynasty.
\end{abstract}

Around the late Middle Kingdom, ca. 1800 BC, the composition of burial equipment - and consequently also the ideology of the tomb - underwent a profound transformation. With the disappearance of wooden models and Coffin Text decoration on the inside of the coffins, the tomb equipment started to be dominated by objects more connected with practices of the daily life. ${ }^{1}$ Contemporary objects for the uppermost elite burials related to the resurrection ritual, the so-called Osirification regalia, became more widespread, and new sets of funerary items ${ }^{2}$ started to be specifically produced (including the first prototypes of shabtis ${ }^{3}$ and heartscarabs). ${ }^{4}$ What led to this change has been widely explored from ritual and religious perspectives, ${ }^{5}$ but it has been less frequently examined from social and economic

\footnotetext{
* In the first instance, I would like to deeply thank Rune Nyord both for organising the seminar in Cambridge and for all his efforts in assembling the volume, certainly not an easy task. I am also grateful to Wolfram Grajetzki for revising the manuscript and Paul Whelan for checking the English. The statistic setting concerning the stela with multiple people is to be credited to Alexander Ilin-Tomich, who kindly shared his data and knowledge. Finally, I also owe to Juan Carlos Moreno García, Christian Knoblauch, Miriam Müller, Nicholas Picardo, Anna Stevens, and Paul Whelan for sharing their articles and information concerning their researches. I am thankful to all the participants to the seminar day for their inspiring presence and fruitful discussion.

${ }^{1}$ Cf. Miniaci, G., Miniature Forms as Transformative Thresholds: Faience Figurines in Middle Bronze Age Egypt (1800 BC-1650 BC) (=BMPES 7), Leuven-Paris-London, forthcoming; Quirke, S., Birth tusks. The armoury of health in context - Egypt 1800 BC. Including publication of Petrie Museum examples photographed by Gianluca Miniaci, and drawn from the photographs by Andrew Boyce (=MKS 3), London 2016.

${ }^{2}$ Grajetzki, W., Tomb treasures of the late Middle Kingdom. The archaeology of female burials. Philadelphia 2014, pp. 147-63.

${ }^{3}$ Miniaci, G., "The case of the Third Intermediate Period "shabti-maker of the Amun domain" Padiamun and the change in conception of shabti statuettes', in JEA 100 (2016), pp. 253-82. See also Nyord, R., "“An image of the owner as he was on Earth". Representation and ontology in Middle Kingdom funerary images', in: Miniaci, G., Betrò, M., Quirke, S. (eds). Company of Images. Modelling the ancient imaginary world of the Middle Kingdom. Proceedings of the international conference held on 18th-20th September in London, UCL, OLA 262, Leuven 2017, pp. 337-59.

${ }^{4}$ Miniaci, G., Haynes, J., Lacovara, P., 'Heart-scarabs in the transition between the Second Intermediate Period and the early Eighteenth Dynasty: BMFA 72.1346', SAK 47 (2018).

${ }^{5}$ Willems, H., Chests of life. A study of the typology and conceptual development of Middle Kingdom standard class coffins (=MVEOL 25), Leiden 1988, pp. 240-3; Bourriau, J., 'Change of body position in Egyptian burials
} 
viewpoints. ${ }^{6}$ In the logic of burial assemblage, scholars tended to dichotomise the ensemble of the grave into two different broad categories: on the one hand, is the body, and, on the other hand, all of the other countable objects. In this regard, the objects deposited in the grave were often considered the most endemic target to be explored in order to reconstruct the mortuary ideology, frequently used to visually support the relative textual sources. ${ }^{7}$ Human bodies, the real ontological centre of the burial itself and regulated by physical anthropological dictates, were often either left aside or studied separately, considered more useful for providing information about age, gender, demography, and health issues. ${ }^{8}$ Ultimately, the correlation between the change in burial equipment composition/funerary beliefs and the number of individuals sharing the same funerary context has received little attention. ${ }^{9}$

Yet, in ancient Egypt the arrangement of bodies in funerary rooms was not regulated by random circumstances, but rather followed precise rules. ${ }^{10}$ For instance, an inscription in the Old Kingdom tomb of Merefnebef at Saqqara explicitly bans members of his family/household from making their own burial there: 'the one [Merefnebef] whose servants do not make a burial inside this tomb, the one [Merefnebef] who does not bury any people inside his tomb, neither his children nor his brother nor his $k a$-servant'. ${ }^{11}$ In this specific instance, archaeological evidence seems to support what is stated in the textual information, since the plan of Merefnebef's mastaba shows only a single burial shaft with no space for any other interments. ${ }^{12}$

Wolfram Grajetzki has already shown that in the Early Dynastic-Old Kingdom, ${ }^{13}$ single burials represented the preferred (ideal) type of inhumation among Egyptian society: ${ }^{14} \mathrm{a}$

from the mid XIIth Dynasty until the early XVIIIth Dynasty', in: Willems, H. (ed.), Social aspects of funerary culture in the Egyptian Old and Middle Kingdoms. Proceedings of the international symposium held at Leiden University 6-7 June, 1996, 1-20, Leuven 2001, pp. 1-20; Grajetzki, W., 'Box coffins in the late Middle Kingdom and Second Intermediate Period', EVO 30 (2007), pp. 41-54; Miniaci, G., Quirke S., 'Reconceiving the tomb in the late Middle Kingdom: the burial of the Accountant of the Main Enclosure Neferhotep at Dra Abu al-Naga', BIFAO 109 (2009), pp. 357-70.

${ }^{6}$ Cf. Quirke, S., Birth tusks, pp. 577-604; Miniaci, G., 'Burial equipment of rishi coffins and the osmosis of the 'rebirth machine' at the end of the Middle Kingdom', in: Taylor, J.H., Vandenbeusch, M. (eds), Ancient Egyptian Coffins. Craft traditions and functionality, Leuven 2018, pp. 247-73.

${ }^{7} \mathrm{Cf}$. Willems, H., 'The embalmer embalmed: remarks on the meaning of the decoration of some Middle Kingdom coffins', in: Dijk, J. van (ed.), Essays on ancient Egypt in honour of Herman te Velde, Groningen 1997, pp. 343-372.

${ }^{8}$ Cf. Bush, H., Zvelebil, M. (eds.), Health in past societies. Biocultural interpretations of human skeletal remains in archaeological contexts, Oxford 1991; Meskell, L., Archaeologies of social life. Age, sex, class et cetera in ancient Egypt, Oxford 1999.

${ }^{9}$ Cf. recently Willems, H., Les textes des sarcophages et la démocratie. Éléments d'une histoire culturelle du Moyen Empire Égyptien, Paris 2008, pp. 149-82 and Willems, H., Historical and archaeological aspects of Egyptian funerary culture. Religious ideas and ritual practice in Middle Kingdom elite cemeteries (=CHANEA 73), Leiden-Boston 2014, pp. 124-229.

${ }^{10}$ With several exceptions due to multiple factors, not least personal contingent decisions, $c f$. Miller, D., Artefacts As Categories. A study of Ceramic Variability in Central India, Cambridge 1985; Tilley, C., Metaphor and Material Culture, Oxford 1999.

${ }^{11}$ Mysliwiec, K. (ed.), Saqqara I: The tomb of Merefnebef, Warszawa 2004, vol. I, pp. 80-2.

${ }^{12}$ Mysliwiec Saqqara I, vol. II, 506, plan 507, section.

${ }^{13}$ Grajetzki, W., 'Multiple burials in ancient Egypt to the end of the Middle Kingdom', in: Grallert, S., Grajetzki, W. (eds), Life and afterlife in ancient Egypt during the Middle Kingdom and Second Intermediate Period, London 2007, pp. 17-21.

${ }^{14}$ For ancient Egypt it is not always possible to differentiate between royal, upper, middle and lower class, since the archaeological documentation available today is rather unbalanced, with a notable predominance in favour of the uppermost levels of society. Anna Stevens, in her study of South Tomb and North Tomb cemeteries at Amarna, has shown how the middle and - perhaps - lower class burial practices may follow rules that completely escape the standards which are instead visible - and thus known to us - in other (higher/richer) 
single individual was provided with his own funerary room separated from other inhumations. For instance, in the Old Kingdom provincial cemetery of Nag ed-Deir, the general rule of body interment followed the pattern 'single grave/structure = single body'. Thus, in area 'N 3500-5000', in relation to the type iv graves identified by George Reisner and belonging to the Second-Third Dynasties, 81 individuals were recorded in 81 graves, ${ }^{15}$ with a rate of ' 1 (grave):1(individual)'. ${ }^{16}$ Although such a strict ratio is rather occasional, it mirrors a general preference towards single interment, which is usually widely altered by several factors, not the least economic, personal, and social needs. In this period, the practice of inhumations in single graves seems to concern both the higher social classes and the officials of middle rank. ${ }^{17}$ During the late Old Kingdom-early Middle Kingdom, the number of funerary structures containing several burial apartments and therefore including more than one person under their architectonic umbrella rapidly increased in frequency, including also more bodies into a single burial chamber ${ }^{18}$ However, in this period the phenomenon of multiple inhumations inside a single grave still tended to remain a marginal custom among the upper levels of society, who privileged individual funerary structures. ${ }^{19}$ During the late Middle Kingdom, by the time of Senusret III, the practice of multiple burials became more widespread across the whole country and it was more visible at all social levels, reaching also the uppermost segments of society and the royal court (as in Senusret III's and Khendjer's pyramid complexes). ${ }^{20}$

\section{Definition of multiple burial types}

Although constantly employed, the prenominal attributive adjective 'multiple' put in front of the term 'burial' increases semantic confusion, above all in Egyptological literature, where there are no specific studies on the subject. ${ }^{21}$ The degree of variance between different types of multiple burials is remarkable, yet the definition 'multiple burials' is often used unconstrained without any further specification other than the mere numerical relationship:

contexts, see Stevens, A., Dabbs, G.R., Shepperson, M., King Wetzel, M., 'The cemeteries of Amarna', in Kemp, B.J., 'Tell el-Amarna, 2014-15', JEA 101 (2015), pp. 23-4.

${ }^{15}$ Reisner, G.A., A provincial cemetery of the pyramid age. Naga-ed-Dêr, part III. (=University of California publications in Egyptian archaeology 6), Oxford-Berkeley 1932, p. 19.

${ }^{16}$ For exceptions see Dębowska-Ludwin, J., 'Multiple and disordered burials as special funerary practices in early Egypt: examples from Tell el-Farkha’, Folia orientalia 47 (2010), pp. 371-8.

17 Jánosi, P., "Im Schatten” der Pyramiden - Die Mastabas in Abusir. Einige Beobachtungen zum Grabbau der 5. Dynastie', in: Bárta, M., Krejčí, J. (eds), Abusir and Saqqara in the year 2000 (=Archív orientální. Supplementa 9), Praha 2000, pp. 445-66; Jánosi, P., 'Aspects of mastaba development: the position of shafts and the identification of tomb owners', Archív Orientální 70/3 (2002), pp. 337-50.

${ }^{18}$ Seidlmayer, S.J., 'Wirtschaftliche und gesellschaftliche Entwicklung im Übergang vom Alten zum Mittleren Reich: ein Beitrag zur Archäologie der Gräberfelder der Region Qau-Matmar in der Ersten Zwischenzeit', in: Assmann, J., Davies, V., Burkard, G. (eds.), Problems and priorities in Egyptian archaeology, London-New York 1987, pp. 175-217; Seidlmayer, S.J., Gräberfelder aus dem Übergang vom Alten zum Mittleren Reich: Studien zur Archäologie der Ersten Zwischenzeit (=Studien zur Archäologie und Geschichte Altägyptens 1), Heidelberg 1990, pp. 403-5; Seidlmayer, S.J., 'Die Ikonographie des Todes', in: Willems, H. (ed.), Social aspects of funerary culture in the Egyptian Old and Middle Kingdoms. Proceedings of the international symposium held at Leiden University 6-7 June, 1996, 205-252. Leuven 2001, pp. 211-31; Donnat, S., Moreno García, J.C., 'Intégration du mort dans la vie sociale égyptienne à la fin du troisième millénaire av. J.-C.', in: Mouton, A., Patrier J. (eds.), Life, death and coming of age in antiquity. Individual rites of passage in the ancient Near East and adjacent regions, Leiden 2014, 188-202.

${ }^{19}$ Grajetzki, W., Burial customs in ancient Egypt. Life in death for rich and poor, London 2003, pp. 39-53. Moreno García, J.C., 'La gestion sociale de la mémoire dans l'Egypte du IIIe millénaire : les tombes des particuliers entre utilisation privée et idéologie publique', in: Fitzenreiter, M., Herb, M. (eds.), Dekorierte Grabanlagen im Alten Reich-Methodik und Interpretation (=IBAES 6), London 2006, pp. 226-31.

${ }^{20}$ See for instance, Grajetzki, Tomb treasures, 75.

${ }^{21}$ Cf. Seidlmayer, Gräberfelder, pp. 398-430; Grajetzki, in: Grallert, Grajetzki (eds), Life and afterlife. 
number of 'individual(s) vs structure'. Therefore, within the large corpus of 'multiple burials', deep conceptual differences can be highlighted as a result of the differences in the methodologies used to associate one or more bodies within a grave. Building on Nick Stoodley's classification for Anglo-Saxon multiple interments, ${ }^{22}$ I have proposed in a recent article published in the Cambridge Archaeological Journal a more accurate classification of multiple burials in ancient societies based on two main factors, which may have influenced the association of bodies: 1 ) architecture of the feature; 2 ) temporality. ${ }^{23}$

\section{Architecture of the feature}

Architectural isolation represents the conditio sine qua non for the definition of multiple burial. However, architectural isolation is variably changing according to the frame of reference. For instance, a single burial entrance (such as a shaft), with one superstructure and possibly a unique cult place, can lead to several separate burial chambers with each containing a single deceased; ${ }^{24}$ such architectural features represent an ambiguous case, where the minimum requirement for classification as a multiple burial changes according to the point of view (external $=$ several bodies grouped under a single structure; internal = bodies clearly separated from each other by defined underground architecture). According to architectural isolation criteria, type a. 'direct multiple burials', and type b. 'indirect multiple burials' can be distinguished. Direct multiple burials indicate more bodies grouped in a single funerary space, which is not only architectonically but also ideologically and intentionally well separated from other burial spaces; e.g. several inhumations in a single funerary chamber blocked by a wall. Indirect multiple burials feature individual interments, which may be separated from each other by an architectural element (such as a door, a wall, earth, or any type of blockade) but which are, nonetheless, intentionally and ideologically connected within a unique funerary space; e.g. single compartments radiating from a unique entrance and each containing an individual deposition. ${ }^{25}$

\section{Temporality}

Temporality is one of the key factors that regulate funerary processes. An essential division, which involves temporality, is made between 'primary' (type c) and 'secondary' (type d) burials. In 'primary burials' the individuals are deposited in their original place of interment and they were not moved or otherwise manipulated afterwards. In 'secondary burials' the individuals had been moved from their original interment location and re-deposited in a different place. To these main temporal aspects can be added also a third division, which straddles primary and secondary depositions: 'delayed burials' (type e). The lapse occurring from the death of the individual and the act of interment in the grave can also be protracted in time.

Grouped inhumations in individual graves usually stress also other different temporal aspects: simultaneity, consecutiveness, and discontinuity, thus identifying the following

\footnotetext{
${ }^{22}$ Stoodley, N., 'Multiple burials, multiple meanings? Interpreting the early Anglo-Saxon multiple interment', in: Lucy, S., Reynolds, A. (eds.), Burial in Early Medieval England and Wales (=Society for Medieval Archaeology Monograph 17), London 2002, pp. 103-10.

${ }^{23}$ Miniaci, G., 'Multiple burials in ancient societies: theory and methods from Egyptian archaeology', in Cambridge Archaeological Journal 29 (2018).

${ }^{24}$ See for instance Arnold, D., Middle Kingdom tomb architecture at Lisht (=PMMA 28), New Haven-London 2007, p. 83, pl. 159c-e.

${ }^{25}$ In the $1800 \mathrm{BC}$ cemeteries of Lisht and Dahshur there are several examples of isolated inhumations arranged in underground rooms around a unique entrance off the shaft ( $c f$. Arnold, D., The pyramid complex of Senwosret I. The South Cemeteries of Lisht 3. (=PMMA 25), New York 1992, pp. 41-6, pls. 52-4; Arnold, D., The Pyramid Complex of Senwosret III at Dahshur: Architectural Studies (=PMMA 26.), New York 2002, 69-74, pls. 69-70; Arnold, Middle Kingdom tomb architecture, 83, pl. 159c-e).
} 
types: f. 'simultaneous multiple burials', g. 'sequential multiple burials' and h. 'intrusive multiple burials'. 'Simultaneous multiple burials' stress temporal immediacy, as a single spot on the timeline: burials containing two or more individuals interred at the same time; this might have been the result of a coincident death-event, such as war, a common disease or epidemic, a ritual killing; the individuals may have died more-or-less at the same time. 'Sequential multiple burials' stress instead temporal proximity, defining those graves which were re-opened at some distance in time after their first closure, in order to allow a second, third or even more new interments to be made into existing graves. The lapse of time passing between the original interment and the subsequent reopening(s) should not be too long, otherwise the consecutiveness of the action will have been lost. Two of the main aspects that sequential multiple burials intend to highlight are the intentionality of the re-use of the same funerary space and a common link or a direct connection between the burials. 'Intrusive multiple burials' focus on the aspect of discontinuity in time: interments enter an earlier grave either deliberately or accidentally after a break in time, which in most of the cases correspond to a phase of disuse or abandon. In the case of the intrusive multiple burials there is no evident direct link with the original owner or earlier occupants. ${ }^{26}$

\section{Table 01}

\section{The widespread of sequential multiple burials in the late Middle Kingdom}

In the late Middle Kingdom, funerary transformations did not only involve the range of objects deposited in the burial, but also the number of bodies associated in the grave itself. In particular, sequential multiple burials are documented in a high number of sites, being widespread across all Egypt, and for a large part of society, including royalty and the uppermost part of society. It is important to stress that the late Middle Kingdom, in comparison with the previous situation, saw an increase of multiple burials into a single, architectonically isolated, funerary space ('direct multiple burial' type). ${ }^{27}$ This phenomenon is substantially different from the situation registered in the late Old Kingdom and First Intermediate Period, when the number of burials under the same cultic - or symbolic building (such as the enclosure of a pyramid or of a mastaba) notably increased, as remarked by Seidlmayer, ${ }^{28}$ but the bodies still tended to be separated in 'nuclear' chambers. ${ }^{29}$ The cemetery M.X of Mirgissa shows rather clearly that shift, through the analysis of documented 168 tombs, whose dating is spanning from the Middle Kingdom to the early New Kingdom: the funerary structures belonging to the first phases privileged rooms created for single interments, while in the latter phases (late Middle Kingdom/Second Intermediate Period) an architectural shift towards larger funerary rooms for a large number of deceased is clearly recognisable. ${ }^{30}$ For instance, the tomb $\mathrm{T} 69$, found intact by the excavators, contained pottery

\footnotetext{
${ }^{26} C f$. Wickholm, A., 'Reuse in the Finnish Cremation Cemeteries under Level Ground: Examples of Collective Memory', in: Oestigaard, T., Fahlander, F. (eds.), The Materiality of Death. Bodies, Burials, Beliefs (=BAR international series 1768), Oxford 2008, pp. 89-97, for an ideological reuse of Middle and Late Iron Age cemeteries in Finland and Estonia.

${ }^{27}$ Richards, J., Society and death in ancient Egypt. Mortuary landscapes of the Middle Kingdom, Cambridge 2005, p. $104 \mathrm{ff}$.

${ }^{28}$ Seidlmayer, in: Willems (ed.), Social aspects.

${ }^{29}$ Cf. Callender, V.G., 'A contribution to the burial of women in the Old Kingdom', Archív Orientální 70/3 (2002), p. 308.

${ }^{30}$ Vercoutter, J., Mirgissa II: les nécropoles (=Mission archéologique française au Soudan), Paris 1975, 31.
} 
material which can be attributed to the first phase of use of the cemetery (Ia) ${ }^{31}$ the tomb is made of a pit hewn into the ground, intended for the interment of a single deceased. ${ }^{32}$ Tombs $\mathrm{T} 130$ and $\mathrm{T}$ 131, which belong to the immediately following material culture sub-phases (IbIc), are constituted by several funerary rooms, intended for hosting more than a single deceased. ${ }^{33}$ The architectural change is also accompanied by a radical change in the composition of the burial equipment, as in $\mathrm{T} 130-131$ for the first time appear rishi masks ${ }^{34}$ and new types of pottery.

In addition, the increase in the use of multiple burials in late Middle Kingdom seems to involve to a certain extent also the uppermost and royal classes, which had privileged till that moment isolated funerary spaces. Usually the adoption of the multiple burial system may be related to the paucity of resources and/or distance from economic and consumption centres; however, the fact that the late Middle Kingdom cemeteries directly connected with power and religious centres, such as Dahshur, Hawara, Lisht, Harageh, Abydos and Thebes, display a particular response to the practice of multiple burials, ${ }^{35}$ indicates that the pattern of multiple burials is governed by - or maybe more correctly follows - also other criteria than the economic and (human and physical) geographical ones. For instance, in an area strictly connected with the centre of ancient power (the capital Itjtawy) in the late Middle Kingdom cemetery A at Harageh, a total of 63 burials were found containing human 'countable' remains of which ca. $54 \%$ hosted more than one body: ${ }^{36}$ tombs nos. 30, 36, 70, 104, 136 (2M); tombs nos. 114, 134 (2F); tombs nos. 57, 118 (3M); tombs nos. 48, 71 (3F); tombs nos. 55, 62, 107, 117, 124, 133 (1M-1F); tombs nos. 40, 58 (1M-2F); tomb no. 130 (1M-5F); tombs nos. 7, 50, 80-81, 139 (2M-1F); tombs nos. 59, 97 (2M-2F); tombs nos. 82, 141, 132 (2M-3F); tomb no. 116 (2M-4F); tombs nos. 28, 131 (3M-1F); tomb no. 56 (4M-6F); tomb no. 91 (1M-1child) ${ }^{37}$ Other cemeteries connected with prestige and religious centres, such as Dahshur, Lisht, Abydos, and Thebes, show a notable increase in the use of sequential multiple burials in late Middle Kingdom, which becomes more widespread throughout the country in this period ${ }^{38}$ Also in non-core areas, the multiple burials became more visible in archaeological records: at Edfu, in the south of the country, in a cemetery datable to the period from the late Twelfth Dynasty to the early New Kingdom, inhumations with more than one body became rather common. ${ }^{39}$ In conclusion, while before the late Middle Kingdom multiple burials showed a patchiness pattern, varying according to multiple factors, starting

\footnotetext{
${ }^{31}$ Labelled as phase Ib by Christian Knoblauch, who is studying the different development phases of Mirgissa material culture. Paper presented at the international workshop "Second Intermediate Period Assemblages - The Building Blocks of Local Relative Sequences of Material Culture”, Wien 22-23 June 2017.

${ }^{32}$ Vercoutter, Mirgissa II, p. 84.

${ }^{33}$ Vercoutter, Mirgissa II, p. 186-200. Phase division based upon the work of Christian Knoblauch.

${ }^{34}$ Cf. Miniaci, G., Rishi coffins and the funerary culture of Second Intermediate Period Egypt (=GHP Egyptology 17), London 2011.

${ }^{35}$ Grajetzki, in: Grallert, Grajetzki (eds), Life and afterlife, pp. 24-9.

${ }^{36}$ Harageh data should be taken with great caution, waiting for more detailed researches; preliminary data may be inaccurate, since the whole area underwent a - documented - phase of disturbance, which could have happened either closer to the time of deposition or in the New Kingdom when the cemetery was still in use. However, most of the burials show multiple or larger funerary rooms, as they were originally planned for hosting more than a deceased. Also the late Middle Kingdom burial equipment seems to point out to multiple interments, $c f$. Miniaci, G., 'Collecting groups: the archaeological context of the late Middle Kingdom Cemetery A at Harageh', EDAL 4 (2013-2014), pp. 43-60, based on Engelbach, R., Harageh, London 1928.

${ }^{37} \mathrm{~F}$ and $\mathrm{M}$ are used here to respectively label female and male individuals, following the ratio reported by the excavators; nonetheless methods in use at that time to differentiate between women and men can be questionable, see Engelbach, Harageh.

${ }^{38}$ Grajetzki, in: Grallert, Grajetzki (eds), Life and afterlife, pp. 24-9.

${ }^{39}$ Michalowski, K., Desroches, Ch., de Linage, J., Manteuffel, J., Zejmo-Zejmis, M., Tell Edfou 1939 (=Fouilles franco-polonaises 3), Le Caire 1950, pp. 61-100. N.b. most of the burials have been found heavily disturbed and further studies are needed.
} 
from the late Middle Kingdom onwards they became a more frequent component of the burial landscape of ancient Egypt.

According to the French anthropologist Robert Hertz, death did not represent an abrupt withdrawal of an individual from the earth (even the body does not disappear all at once) but rather a 'changement d'état d'un individue'. ${ }^{40}$ The long funerary rituals performed by ancient societies had the effect of transforming the deceased into a new entity with new - ritually established - social relations. The burial of an individual was a reconfiguration of his identity in order to cope with the physical, emotional, social, and ideological demands of death. ${ }^{41}$ The impact of an individual on the living did not stop with his/her death but continued afterwards, for an unpredictable period of time, involving an incalculable number of persons: from a few days to centuries, from the tight domestic sphere to a national/international level. ${ }^{42}$ Therefore, burial demography can also mirror a structural change of society. One of the roots of deep changes inside the demography of death, such as the increase of sequential multiple burials around the first quarter of the Second Millennium BC in Egypt, must be researched also in social transformations. From a purely cognitive point of view, a multiple burial delivers a signal completely different from a single burial; in other words, it mirrors a changed attitude within the society. Such changed social attitudes, apparently imperceptible, can be glimpsed through archaeological, textual and iconographic sources.

\section{Setting the framework: the 'household' structure in the Middle Kingdom}

It has often been postulated that multiple sequential burials (except for the case of intrusive burials) may have represented family interments. However, in the absence of explicit evidence or DNA analysis, any inference of kinship or lineage-based relations can lead to assumptions. The case of the early Eighteenth Dynasty tomb of Noferkhawet and Rennofer discovered by the Metropolitan Museum of Art Expedition in the Asasif at Thebes may be instructive (Fig. 02). ${ }^{43}$ The underground structure, consisting of a rectangular shaft and several side chambers, hosted ten burials. In the western rooms lay the bodies of Noferkhawet and Rennofer, who were in an indisputable conjugal relation attested by documents found inside the tomb itself. In the eastern rooms there were three burials belonging to a daughter Ruyu, a son Amenemhat, a person named Bakamun/Baki, and five anonymous individuals (two young boys, two infants, an adult woman).$^{44}$ Only one of them, Ruyu, has been plausibly identified from a statue inscription as daughter of Noferkhawet and Rennofer; ${ }^{45}$ the other individuals could equally belong to either the same or to a different family. Nonetheless, this tomb has often been cited as an emblematic example of 'a family mausoleum, deliberately constructed to accommodate a sequence of burials and to allow for numerous openings and closings as necessary, over a relatively long span of time'. ${ }^{46}$

\footnotetext{
${ }^{40}$ Hertz, R., Sociologie religieuse et folklore, 2nd ed., Paris 1970, p. 73.

${ }^{41}$ Ekengren, F., 'Contextualizing Grave Goods: Theoretical Perspectives and Methodological Implications', in: Stutz, L.N., Tarlow, S., Ekengren, F. (eds.), The Oxford Handbook of the Archaeology of Death and Burial, Oxford 2013, pp. 173-94.

${ }^{42}$ Donnat, Moreno García, in: Mouton, A., Patrier, J. (eds.), Life, death and coming of age in antiquity; cf. the indigent man who died and was shortly forgotten by his own family within one generation and king Amenhotep I whose cult endured till the Late Period, Hollender, G., Amenophis I. und Ahmes Nefertari: Untersuchungen zur Entwicklung ihres posthumen Kultes anhand der Privatgräber der thebanischen Nekropole (=SDAIK 23), Berlin-New York 2009, pp. 9-10.

${ }^{43}$ Hayes, W.C., 'The Tomb of Nefer-khewet and his Family', BMMA 30 (1935), pp. 17-36.

${ }^{44}$ Dorman, P.F., 'Family burial and commemoration in the Theban Necropolis', in: Strudwick, N., Taylor, J.H. (eds.), The Theban necropolis. Past, present and future, London 2003, pp. 34-7.

${ }^{45}$ Cassirer, M., 'A Granite Statue Group of the Eighteenth Dynasty', JEA 41 (1955), pp. 72-4.

${ }^{46}$ Dorman, in: Strudwick, Taylor (eds.), The Theban necropolis, 36.
} 
Although the actual reference to this type of burial as a 'family burial' is methodologically incorrect, the logic of the 'multiple and sequential' inevitably generates in our minds the premise of a close link between the individuals inside a single burial. Therefore, instead of denying such a premise or, even worse, assuming blood lineage links, another social structure may provide a model by which multiple burials can be explored with more caution.

The concept of 'family' is rather problematic, since it has no clearly defined boundaries, straddling blood, social and economic bonds, and changes over time and across geographical areas, being continuously shaped by different cultural and political milieu. ${ }^{47}$ In modern perception, the word 'family' is mostly related to a conjugal family unit (CFU), where a group of people is affiliated either by consanguinity (= recognised birth) or by affinity (= marriage or any other relationship, such as adoption), and possibly by co-residence (= same house). Also family size may change according to other parameters: a. the simple family, which can be defined as nuclear or biological, comprising the conjugal couple and their children; b. the extended family, including one or more relatives; c. the multiple family including two or more conjugal family units co-residing in the same space and under a common head. ${ }^{48}$ However, although the CFU can be an efficient model for tackling genealogy, inheritance, succession, marriage, post-marital events, and also - though only partially - socio-economic questions, it cannot be the exclusive manner from which to approach societal structure. When unquestioningly applied to the study of a past society, the CFU model reduces research to a rigid lineage-based approach, which cannot fully enlighten us about socio-economic patterns, and, moreover, if not sustained by concrete data, can lead to completely misleading conclusions.

In order to contrast the rigidity and the ambiguity of classifying societies according only to their kinship systems, ${ }^{49}$ anthropologists explored the idea that relational, social, and economic bonds could be structured not merely around blood lineage but also around the material and immaterial networks of the 'house'. Claude Lévi-Strauss first proposed the model of the 'house societies' (sociétés à maisons) intended as a moral person, which encompasses various permutations of people, property and residential buildings.

'Personne morale détentrice d'un domaine composé à la fois de biens matériels et immatériels, qui se perpétue par la transmission de son nom, de sa fortune et de ses titres en ligne réelle ou fictive, tenue pour légitime à la seule condition que cette continuité puisse s'exprimer dans le langage de la parenté ou de l'alliance, et, le plus souvent, des deux ensemble $e^{50}$

The household model proposed by Lévi-Strauss is controversial ${ }^{51}$ as it involves multiple temporalities (its composition and structure may change on a seasonal scale or at any timescales) and the identity of its members and their relationships are rather fluid in time and space, as the same individuals can be associated with more than one household in the same or

\footnotetext{
${ }^{47}$ Laslett, P., 'Introduction: the history of the family', in: Laslett, P. (ed.), Household and Family in Past Time, Cambridge 1972, pp. 1-89.

${ }^{48}$ Laslett, in: Laslett (ed.), Household, pp. 28-32, see table 1.1.

${ }^{49} \mathrm{Cf}$. Olabarria, L., 'A Question of Substance: Interpreting Kinship and Relatedness in Ancient Egypt', Journal of Ancient Egyptian Interconnections 17 (2018), pp. 88-113.

${ }^{50}$ Lévi-Strauss, La Voie des masques, Genève 1979, 47.

${ }^{51}$ Allison, P.M., 'Introduction', in: Allison, P.M. e(ed.), The Archaeology of Household Activities, London-New York 1999, pp. 1-18, esp. pp. 5-6; Alexander, R.T., 'Mesoamerican house lots and archaeological site structure: Problems of inference in Yaxcaba, Ycatan, Mexico, 1750-1847', in: Allison, P.M. e(ed.), The Archaeology of Household Activities,London-New York 1999, pp. 80-2.
} 
different times. ${ }^{52}$ However, it has the advantage of moving the social organization beyond both the rigid patterns of consanguinity/affinity ties and the material limits of the building itself. The household is a social entity that may use multiple strategies to recruit, retain, and replace members, still functioning on the basis of kinship, but often superseding genealogical ties (for instance, via fictional or metaphorical kinship) when facing economic and political interests. ${ }^{53}$ Legitimation of its membership is accomplished through a unifying ideology in terms of family - genealogically-based kinship - or alliance relationships, which can develop from economic, juridical, religious, or social factors. This unifying household ideology is materialised in the wealth of its estate, founded in the material substance consisting of its members, its architecture, its fields, the bodies and icons of its ancestors, its places of origin, its origin narratives, and its heirlooms. ${ }^{54}$

Although research into domestic archaeology of ancient Egypt is still in its embryonic state, ${ }^{55}$ it does show that archaeological and textual evidence foster the opinion that an economic system based on household principles was in operation besides or strictly interconnected with the central state apparatus. ${ }^{56}$ During the Predynastic, according to Marcelo Campagno, kinship was probably intended as the main social organisation in village communities, as testified by the clustering of burials within cemeteries at Badari, Naqada and Hierakonpolis. ${ }^{57}$ Sources from the early to late Middle Kingdom indicate that a system which included not only members biologically related but also non-relational ties was already well in use. Some specific cases testify that society in the Middle Kingdom was partially (?) structured around household principles. A series of early Middle Kingdom (time of Senusret I) letters and accounts concerning family members of the middle-class funerary priest Heqanakht, reveal the composition and functioning of his household: eight family (CFU: extended family) members (his wife, three children, his widowed mother, his younger brother and younger and older sisters); at least ten dependents - functionaries and servants - (the foreman Heti and the steward Merisu with their families, the scribe Sihathor, the farm worker Sinebniut, and two unnamed servants). ${ }^{58}$ Heqanakht's social house included also other households (Mentunakht, Tjai's son Nakht, and Khetyankhef) with whom he maintained

\footnotetext{
52 Matthews, W. 'Defining Households: Micro-Contextual Analysis of Early Neolithic Households in Zagros, Iran', in: Parker, B.J., Foster, C. (eds), New Perspectives on Household Archeology, Winona Lake 2012, pp. 183-216.

${ }^{53}$ Gillespie, S.D., 'Beyond Kinship: An Introduction', in: Joyce, R.A., Gillespie, S.D. (eds.), Beyond Kinship. Social and Material Reproduction in House Societies, Philadelphia 2000, p. 15.

${ }^{54}$ Beck Jr, R.A., 'The Durable House: Material, Metaphor, and Structure', in: Beck Jr, R.A., The Durable House. House Society Models in Archaeology, Carbondale 2007, p. 10.

${ }^{55}$ See above all Müller, M., 'New approaches to the study of households in Middle Kingdom and Second Intermediate Period Egypt', in: Miniaci, G., Grajetzki, W. (eds.), The world of Middle Kingdom Egypt (2000 1550 BC). Contributions on archaeology, art, religion, and written sources (=MKS 1), vol. I, London 2015, pp. 237-255 and Kóthay, K.A., 'Houses and households at Kahun: bureaucratic and domestic aspects of social organization during the Middle Kingdom', in: Győry, H. (ed.), Mélanges offerts à Edith Varga. 'Le lotus qui sort de terre' (=Bulletin du Musée Hongrois des Beaux-Arts: Supplément 2001), Budapest 2002, pp. 349-68. This may be due principally to the difficulties in setting up a unitary urban archaeology strategy, $c f$. Moeller N., The Archaeology of Urbanism in Ancient Egypt. From the Predynastic Period to the End of the Middle Kingdom, New York 2016.

${ }^{56}$ Moreno García, J.C., 'Households', in: Frood, E., Wendrich, W. (eds.), UCLA Encyclopedia of Egyptology, Los Angeles 2012, http://digital2.library.ucla.edu/viewItem.do?ark=21198/zz002czx07.

${ }^{57}$ Campagno, M., 'Kinship and the emergence of the state in Egypt', BACE 11 (2000), pp. 35-9; Campagno, M., 'Patronage and other logics of social organization in ancient Egypt during the IIIrd millennium BCE', JEgH 7/1 (2014), pp. 14-24.

58 Allen, J.P., The Heqanakht papyri (=PMMA 27), New York 2002, pp. 107-17; Picardo, N., 'Hybrid households: institutional affiliations and household identity in the town of Wah-sut (South Abydos)', in: Müller, M. (ed.), Household studies in complex societies: (micro) archaeological and textual approaches, Chicago: 2015, pp. 266-8.
} 
relationships with individual persons. ${ }^{59}$ Similarly, the biographical inscription and painted decoration of Khnumhotep II's tomb (no. 3) at Beni Hasan includes a large number of individuals apparently without any kinship relationship to him, yet with a remarkable substitution - in comparison with Old Kingdom scenes - of familiar ties with socio-economic relations. ${ }^{60}$ The household structure is evident also in archaeological remains: in the town of Wah-sut, a state planned settlement attached to the funerary temple of Senusret III at South Abydos, a number of late Middle Kingdom houses seem to have been both domestically oriented, serving as residential housing for one or more families, and officially structured, since a range of institutional activities were carried out inside these buildings. ${ }^{61}$

\section{Social transformations, 1800-1650 BC}

In the late Middle Kingdom (starting ca. 1800 BC), especially under the reign of Senusret III, large administrative reforms can be seen: the centralisation of power with a selective decrease of regional power, the increase of income deriving from military control and exploitation of adjacent areas, all of which must have led to the rise and bustle of social and economic mobility ${ }^{62}$ At least four pieces of evidence seem to testify to the depth of, and rather visible change in, social organisation, which can also directly mirror the spread of multiple burials at the end of Middle Kingdom: a) an increase of plurality of people named/represented on stelae; b) a lexical deviation inside the vocabulary related to 'familial' groups; c) the interruption in the archaeological record of the texts known as 'letters to the dead'; d) the introduction of a new architectural feature in the eastern Delta, the 'house of the dead'.

\section{Targeting the links between social transformation and changes in burial practice}

\section{a) increase of plurality of people named/represented on stelae}

At the end of the Twelfth Dynasty, it can be noticed a drastic increase of the number of person names and representations on the stelae, that gradually declined thereafter. ${ }^{63}$ For instance, in the early to mid-Twelfth Dynasty (Amenemhat I to Amenemhat II) stelae, the median number of persons named ${ }^{64}$ is 7 (arithmetic mean: 10); ${ }^{65}$ while in the late Twelfth Dynasty (Senusret III to Amenemhat IV) stelae, ${ }^{66}$ the median number of persons named is 14 (arithmetic mean: 16). In the Second Intermediate Period the average number of persons named on stelae progressively decreased: 12 in the Thirteenth

\footnotetext{
${ }^{59}$ Picardo, in: Müller (ed.), Household studies, pp. 266-8.

${ }^{60}$ Nelson-Hurst, M.G., 'The (social) house of Khnumhotep', in: Miniaci, G., Grajetzki, W. (eds), The world of Middle Kingdom Egypt (2000 - 1550 BC). Contributions on archaeology, art, religion, and written sources (=MKS 1), vol. I, London 2015, pp. 262-3.

${ }^{61}$ Picardo, in: Müller (ed.), Household studies, pp. 244-5; - hybrid household -, pp. 258-74.

${ }^{62}$ Grajetzki, W., The Middle Kingdom of Ancient Egypt, London 2006, pp. 57, 139-65; Quirke, S., Titles and Bureaux of Egypt 1850-1700 BC, London 2004; Grajetzki, W., 'Setting a state anew: the central administration from the end of the Old Kingdom to the end of the Middle Kingdom', in: Moreno García, J.C. (ed.), Ancient Egyptian administration, Leiden-Boston 2013, pp. 215-58.

${ }^{63}$ Ilin-Tomich, A., From Workshop to Sanctuary: The Production of Late Middle Kingdom Memorial Stelae (=MKS 6), London 2017, 5.

${ }^{64}$ Names, and not representations, are taken into account for this statistic; i.e. human figures without labels have been not included in the count; while names without representations and also names in filiation formulae are all taken into account. I am deeply indebted to Alexander Ilin-Tomich for drawing such statistics.

${ }^{65}$ Based on non-royal, non-fragmentary stelae (118) from Rita Freed's workshops 1-10, $c f$. Freed, R.E. 'Stela Workshops of Early Dynasty 12', in: Der Manuelian, P. (ed.), Studies in Honor of William Kelly Simpson, vol. 1, Boston 1996, pp. 297-336.

${ }^{66}$ Based on non-royal, non-fragmentary stelae (199) from Ilin-Tomich, A., From Workshop to Sanctuary.
} 
Dynasty, 8 in the late Thirteenth Dynasty-Second Intermediate Period, 6 in the late Second Intermediate Period (Sixteenth and Seventeenth Dynasties). ${ }^{67}$ Also the traditional iconography of private stelae seems to undergo some transformations, as a new type of stelae came into use in the late Middle Kingdom, defined by Evers as 'chessboard pattern' type ${ }^{68}$ and usually improperly labelled in Egyptological literature as 'Familienstelen' (Fig. 03). They display - besides the owner or the commissioner of the stela - a high number of individuals usually placed in a visually separated sector, forming a sort of chessboard. These persons are usually marked with kinship epithets in relation to the stela owner, i.e. 'his father', 'his mother', 'his brother', 'his sister', 'his wife', 'his son', 'his daughter' ${ }^{69}$ Some of these stelae do not necessarily contain images/visual reproductions of individuals, as in the case of Wien ÄS 195, but they may contain an equivalent morphological display in the form of text, which lists a series of persons with different degrees of relationship to the owner/commissioner of the stela. The term 'Familienstelen' is improperly used since it is immediately evident that not all the individuals represented on the stela have direct blood lineage with the main person, but they also include clients and colleagues. ${ }^{70}$ As noted by Janet Richards, real or fictive kinship networks could have served as 'a moral economy legitimizing rule'. ${ }^{71}$ In a social house, 'kinship or kin-like ties are strategically used to create social relationships and stake out social identities'. ${ }^{72}$ The chessboard pattern stelae became a common layout type from the reign of Amenemhat III onwards ${ }^{73}$ (although at least two examples may date back to the time of Senusret III). ${ }^{74}$ By the end of the Middle Kingdom the need to include more people on the stelae became more compelling and visible in archaeological records $;{ }^{75}$ tantalisingly, this need can be put in connection with the increase of sequential multiple burials. ${ }^{76}$ In parallel with these 'Familienstelen', other diagnostic late

${ }^{67}$ Cf. Franke, D., Egyptian stelae in the British Museum from the 13th - 17th Dynasties. Vol. I.1: Descriptions. Edited by M. Marée. London 2013; Marée, M., 'A sculpture workshop at Abydos from the late Sixteenth or early Seventeenth Dynasty', in: Marée, M. (ed.), The Second Intermediate Period (Thirteenth-Seventeenth Dynasties): Current research, future prospects. Leuven 2010, pp. 241-281.

${ }^{68}$ Evers, H., Staat aus dem Stein. Denkmäler, Geschichte und Bedeutung der ägyptischen Plastik während des Mittleren Reiches, vol. I, Munich 1929, p. 103.

${ }^{69}$ Kaplony-Heckel, U., 'Eine hieratische Stele des Mittleren Reiches (University College London, Inv. Nr. 14487)', JEA 57 (1971), pp. 20-7. Cf. Stewart, H.M., Egyptian Stelae, Reliefs and Paintings from the Petrie Collection. Part 2: Archaic Period to the Second Intermediate Period, Warminster 1979, pp. 31-3 [132], pl. 41; Bourriau, J., Pharaohs and Mortals: Egyptian Art in the Middle Kingdom: Exhibition organised by the Fitzwilliam Museum, Cambridge, 19 April to 26 June, Liverpool 18 July to 4 September 1988, Cambridge 1988, pp. 63-4 [49], 65 [50].

${ }^{70}$ Fitzenreiter, M., 'Überlegungen zum Kontext der "Familienstelen” und ähnlicher Objekte', in: Fitzenreiter, M. (ed.), Genealogie: Realität und Fiktion von Identität; Workshop am 04. und 05. Juni 2004, London 2005, p. 84.

${ }^{71}$ Richards, Society and death, p. 178.

${ }^{72}$ Gillespie, S.D., 'Lévi-Strauss: Maison and Société à Maisons', in: Joyce, R.A., Gillespie, S.D. (eds.), Beyond Kinship. Social and Material Reproduction in House Societies, Philadelphia 2000, p. 35. See also Olabarria, Journal of Ancient Egyptian Interconnections 17, pp. 88-113.

${ }^{73}$ Pflüger, K., 'The Private Funerary Stelae of the Middle Kingdom and their Importance for the Study of Ancient Egyptian History', Journal of the American Oriental Society 67 (1947), pp. 132-3.

${ }^{74}$ Ilin-Tomich, A., From Workshop to Sanctuary, p. 5.

${ }^{75}$ Nelson-Hurst, M.G., 'The increasing emphasis on collateral and female kin in the late Middle Kingdom and Second Intermediate Period: the vivification formula as a case study', in: M. Horn, J. Kramer, D. Soliman, N. Staring, C. van den Hoven, L. Weiss (eds), Current Research in Egyptology 2010: Proceedings of the Eleventh Annual Symposium which took place at Leiden University, the Netherlands January 2010, Oxford 2010, pp. 116-23.

${ }^{76}$ Leprohon, R.J., 'The personnel of the Middle Kingdom funerary stelae', JARCE 15 (1978), pp. 33-8. However, in absence of more in-depth studies, these 'crowded' iconography introduced on the late Middle Kingdom stelae should not be indiscriminately read into a pictorial version of the individuals buried in the same tomb. 
Middle Kingdom (arch-topped and rectangular) stelae/slabs show multiple mummiform figures carved in high-relief (Fig. 04) ${ }^{77}$ In particular, the rectangular slabs incorporate a high number of individuals, ranging in number from two up to eight; the inscriptions carved on these figures do not testify for clear familiar relations among all the individuals represented. ${ }^{78}$ As demonstrated by Paul Whelan, these stelae, usually placed outside the grave, belong to a process of ritual and veneration of multiple deceased. ${ }^{79}$ The almost synchronic growth of both the number of people represented on stelae and the number of people buried in individual funerary rooms could be linked to analogous processes happening at the level of societal structure, where the one is surrounded - in a closer way - by the multiple. Already in the archaeological documentation, Stephan Seidlmayer identified that one of the major changes in the composition of the social system between the Old and the Middle Kingdoms concerned the development of expanded networks of social affiliation centred around highstatus persons. ${ }^{80}$ Such a phenomenon could have increased, possibly also including further social restructuring/transformation, and became more visible at the end of the Middle Kingdom.

\section{b) lexical deviation inside the vocabulary related to 'familial' groups}

The social group called \#b.t, mainly documented in Old Kingdom legal documents and in First Intermediate Period/early Middle Kingdom biographic inscriptions, has been variously translated using a wide range of terms in an attempt to encompass an ancient nuance that still now escapes modern conception: from 'household' (probably the closest to the meaning of the ancient word) to 'extended family', from 'ancestors' ('aïeuls') to 'relatives by blood', from 'domestic group' to a generic 'people'. ${ }^{81}$ This term is also employed in Coffin Text spells 131-146, which have the specific purpose 'to reunite a man with his \#b.t in the necropolis'. According to Harco Willems, who recently analysed spells CT 131-146, the \#b.t seems to comprise some of the closest biological relatives of the deceased (such as his parents, siblings and children), and occasionally the $m r$.t-servants (as an optional category), unexpectedly excluding both the spouse, with presumably all in-laws, and grandparents with all the other ancestors. ${ }^{82}$ The \#b.t seems to have been intended as a corporate body, a legal unit inside the social structure of the late Old Kingdom, First Intermediate Period and early Middle Kingdom. Soon after, this type of 'familial' structure rapidly fell into disuse. While the term \#b.t appears with some frequency in (auto)biographical texts of the late Old Kingdom-early Middle Kingdom, in fact it is absent from written sources of the Middle Kingdom-Second Intermediate Period. ${ }^{83}$ Only $C T$ 146, a spell exclusively attested on late Middle Kingdom coffins (time of Senusret II-Senusret III) of the subordinates of the nomarch Djehutyhotep at Deir el-Bersha, offers a completely different picture of the \#b.t, which can hardly be aligned with the principles in which this term was used in other earlier contexts (including other CT spells). Under the \#b.t-umbrella, CT 146 includes a much larger type and

\footnotetext{
${ }^{77}$ Whelan, P., 'On the context and conception of two "trademark" styles from the late Middle Kingdom Abydos', in: Miniaci, G., Grajetzki, W. (eds), The world of Middle Kingdom Egypt (2000 - 1550 BC). Contributions on archaeology, art, religion, and written sources (=MKS 2), vol. II, London 2016, pp. 285-338.

${ }^{78}$ Whelan, in: Miniaci, G., Grajetzki, W. (eds), The world of Middle Kingdom Egypt, pp. 291-6.

${ }^{79}$ Whelan, in: Miniaci, G., Grajetzki, W. (eds), The world of Middle Kingdom Egypt, pp. 306-14.

${ }^{80}$ Seidlmayer, in: Assmann, Davies, Burkard (eds.), Problems and priorities, pp. 206-14.

${ }^{81}$ Willems, H. 'Family life in the hereafter according to Coffin Texts spells 131-146: a study in the structure of ancient Egyptian domestic groups', in: Nyord, R., Ryholt, K. (eds), Lotus and laurel. Studies on Egyptian language and religion in honour of Paul John Frandsen, Copenhagen, pp. 452-3, esp. fn. 12.

${ }^{82}$ Cf. Li, J., Women, Gender and Identity in Third Intermediate Period Egypt. The Theban Case Study, New York 2016.

${ }^{83}$ Franke, D., Altägyptische Verwandtschaftsbezeichnungen im Mittleren Reich, Hamburg 1983, p. 287.
} 
number of persons, 'father/s, mother/s, children, brother/s, friends, associates, women, concubines, servants, workers and everything belonging to a man in the realm of the dead'

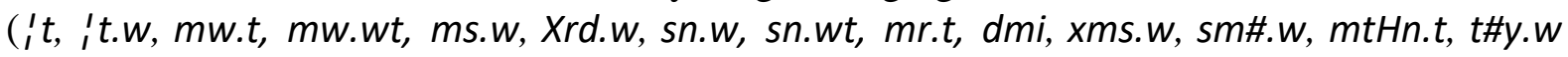
Hm.wt, Hm.w). ${ }^{84}$ Harco Willems explained this dissonance with the fact that by the time CT 146 was produced in the late Middle Kingdom, the \#b.t was no longer an existing social reality. The composers of CT 146 re-interpreted a social concept that was no longer functioning and may not even have been clearly understood by this time. Therefore, the reinterpretation of the \#b.t in CT 146 might reflect a changed social reality that was structured around a larger number of persons who played a more active role in the composition and transmission of the household community. In a formula that explicitly refers to 'reuniting a man with his \#b.t in the necropolis', it is tantalising to consider the possibility that the composition of \#b.t in CT 146 did follow the prevailing societal trend of a greater number of people participating in the socio-economic composition of the household. Although the term $\#$ \#.t was retained in a conservative religious text such as the theological composition of CT, ${ }^{85}$ it could have involuntarily or voluntarily incorporate inside a family terminology new emerging social links that, based on kinship or kin-like ties, were going beyond any bloodrelations. For instance, Franke argued that the term xrd, usually translated as 'child' in the early Middle Kingdom, started to be also used to indicate a subordinate in the administration of the Thirteenth Dynasty. ${ }^{86}$ I have shown elsewhere how the title sA nswt shifted from a kinship related-term to an administrative one, primary used for officials and militars, during the passage from the Middle Kingdom to the Second Intermediate Period. ${ }^{87}$ The 'adjustment' of the term \#b.t in CT 146 may be also influenced by the need to relocate the protection of the deceased inside a 'more crowded' burial demography in the late Middle Kingdom.

\section{c) interruption in the archaeological record of the texts known as 'letters to the dead'}

Between the late Old Kingdom and early Middle Kingdom, probably due to the weakening of royal power, ${ }^{88}$ one of the main concerns of the ancient Egyptians was to keep the relationship between the dead and the living particularly effective in order to allow the deceased to continue to play a cohesive role inside the social and economic fabric. ${ }^{89}$ Such a need explicitly stands out in some written documents of the period: the liturgical spells (CT 38-41) belonging to the Coffin Text corpus, and a number of letters intentionally addressed ${ }^{90}$ and delivered to the deceased himself, a corpus known today as Letters to the Dead. ${ }^{91}$ The aim of the spells $C T$ 38-41 was to guarantee the continued mutual beneficial relationship between the deceased and the living, especially with the deceased's son who stood to inherit his/her

\footnotetext{
${ }^{84}$ De Buck, etc..

${ }^{85}$ See lists in Franke, Altägyptische Verwandtschaftsbezeichnungen, p. 324.

${ }^{86}$ Franke, Altägyptische Verwandtschaftsbezeichnungen, pp. 304-8; cf. Grajetzki, Two Treasurers of the Late Middle Kingdom, Oxford 2001, pp. 74-6.

${ }^{87}$ Miniaci, G., 'Il potere nella 17a dinastia: il titolo "figlio del re" e il ripensamento delle strutture amministrative nel Secondo Periodo Intermedio', in: S. Pernigotti, M. Zecchi (eds), Il tempio e il suo personale nell'Egitto antico : atti del quarto Colloquio, Bologna, 24-25 settembre 2008, Imola, pp. 99-131.

${ }^{88}$ Baines, J., 'Restricted knowledge, hierarchy, and decorum: modern perceptions and ancient institutions', JARCE 27 (1990), pp. 1-23.

${ }^{89}$ Richards, Society and death, pp. 173-80.

${ }^{90}$ On this point see Miniaci, G., "Reuniting philology and archaeology: the "emic" and "etic" in the letter of the dead Qau bowl UC16163 and its context', Z̈̈S 143/1 (2016), pp. 88-105.

${ }^{91}$ Gardiner, A.H., Sethe, K., Egyptian letters to the dead, mainly from the Old and Middle Kingdoms, London 1928; Donnat, S., Écrire à ses morts: enquête sur un usage rituel de l'écrit dans l'Égypte pharaonique, Grenoble 2014; Miniaci, G., Lettere ai morti nell'Egitto antico e altre storie di fantasmi, Flero 2014.
} 
property, and consequently with the members of his/her household. ${ }^{92}$ Similarly, the aim of the Letters to the Dead is to re-issue social connections among the dead and the living. The letters are not addressed by the living to ancestral figures and they do not come from the desire to communicate with the beloved deceased, but are issued to communicate with recently deceased members of the family and to request their tangible support from the netherworld with practical and urgent problems, ranging from illness to disputes over property. ${ }^{93}$ The dead person is expected to intervene from the afterlife and resolve the writer's suffering. This practice had the function of bringing back the recently dead individual within the existing social fabric and offer interconnections, extending his/her presence beyond the death. In more concrete terms, such a letter can be considered as a tangible movement towards the deceased, who was called - using a certain degree of forcefulness, due to the act of writing instead of making an oral request ${ }^{94}$ - to play an active role inside the community.

Although the Letters to the Dead corpus stretches from the Old Kingdom to the seventh century BC, most of the documents belong to a narrow segment of time, between the end of the Old Kingdom/First Intermediate Period and the early Middle Kingdom. ${ }^{95}$ In the late Middle Kingdom and Second Intermediate Period there is clear break in our records. In addition, all of the letters from the late Old Kingdom to the early Middle Kingdom share homogeneity in their style and composition. Later examples, issued after the break of the late Middle Kingdom/Second Intermediate Period, instead, show distinct features, separate from the previous letters and closer to literary or rhetorical compositions. ${ }^{96}$

\section{Table 02}

From the above table, one can see a clear break or interruption in the production of Letters to the Dead from the approach of the late Middle Kingdom through all the Second Intermediate Period and beyond. Although this could be due to the patchy and incomplete survival of archaeological data, it must be considered that this absence could be the mark of a change. Letters to the Dead underline features typical of the missives, sharing almost all their diagnostic features: addressee(s), greeting(s), body with the main corpus of the letter, closing, and recipient. They have the epistolary character of real letters. ${ }^{97}$ Therefore, according to the nature of a 'letter', this type of document was meant to be delivered to individuals who were not easily within reach: the action of writing a letter to a person implied some distance in communication, which is true today as it appears to have been for the ancient Egyptians. Letters to the Dead were the medium connecting the realm of the dead and the living in form of a written message. The disappearance of this practice in the archaeological record during the late Middle Kingdom and the Second Intermediate Period may be the result of chance survival of archaeological remains, but it may also represent the interruption of a need. The

\footnotetext{
${ }^{92}$ Willems, H., 'The social and ritual context of a mortuary liturgy of the Middle Kingdom (CT spells 30-41)', in: Willems, H. (ed.), Social aspects of funerary culture in the Egyptian Old and Middle Kingdoms. Proceedings of the international symposium held at Leiden University 6-7 June, 1996, Leuven 2001, pp. 324-44.

${ }^{93}$ Willems, Les textes des sarcophages, pp. 192-3.

${ }^{94}$ Donnat, S., 'Written pleas to the invisible world: texts as media between the living and dead in pharaonic Egypt', in: Storch, A. (ed.), Perception of the invisible. Religion, historical semantics and the role of perceptive verbs, Köln 2010, pp. 51-80.

${ }^{95}$ Moreno García, J.C., 'Oracles, ancestor cults and letters to the dead: the involvement of the dead in the public and private family affairs in pharaonic Egypt', in: Storch, A. (ed.), Perception of the invisible. Religion, historical semantics and the role of perceptive verbs, Köln 2010, pp. 138-9.

${ }^{96}$ Donnat and Moreno García, in: Mouton, A., Patrier J. (eds.), Life, death and coming of age in antiquity, p. 184; Donnat, Écrire à ses morts, pp. 150, 167-73.

${ }^{97}$ Cf. Wente, E.F., Letters from ancient Egypt (=Writings from the Ancient World 1), Atlanta 1990.
} 
spread of sequential multiple burials meant that tombs became more easily accessible, with manageable entrances to the funerary rooms, allowing them to be continuously opened and reopened, with multiplication of the occasions to see/meet (also figuratively) the deceased, where dead bodies were placed one next to the other. The dead community was connected with the living community in a more fluid way; and the dead were also more strongly interconnected with them. Therefore, the need to leave a written message to the deceased began to lose its potency: why write a letter to a person (albeit a dead one) who is easily accessible? The distance ceased to be an issue because the spiritual presence of the deceased was assured by other actions, including the corporeality given by the sequential multiple burials; thus the Letters to the Dead practice may have faded.

d) introduction of an uncommon architectural feature in the eastern Delta, the 'house of the dead'

Another practice, documented within domestic contexts, may also reflect the late Middle Kingdom need of establishing more tangible and close (in term of physical distance) links with the dead. Confined only to the late Middle Kingdom and exclusively localised in the northeast of the country, i.e., in the settlement of Avaris (Tell el-D'aba), the 'house of the dead' (Totenhäuser) represent an unusual architectural element attached to the main buildings of domestic complexes. These houses display a single room which incorporates a tomb in the centre. This type of structure, despite its close proximity to the dwelling rooms (which were often adjunct to the bedroom), was accessible only from an external passageway (outside courtyard) and not from the internal areas of the house itself. The recovery of benches and offering pits with the remains of feasts, together with evidence for the presentation of offerings and pottery used for libations, seems to reinforce the impression that specific cults and ceremonies with a number of participants were held inside these 'rooms'. ${ }^{98}$ Miriam Müller has recently advanced, in relation to an in-depth analysis of Estate 1 in the area F/1 at Tell el- D'aba (Fig. 05), the suggestion that the buried individuals found in the main tomb of these 'houses of the dead' may represent the household master. Other people probably connected with him were buried in additional pits/tombs along the sides or in other areas of the estate. It must be acknowledged that the act of burying the deceased within the settlement is uncommon to Egyptian customs, which always tended to separate dwelling places and burial spaces. ${ }^{99}$ More frequently, instead, Near Eastern traditions testify a more fluid space arrangement between areas for the living and the dead. ${ }^{100}$ Therefore, scholars have suggested

\footnotetext{
${ }^{98}$ Kopetzky, K., 'Burial practices and mortuary rituals at Tell e-Dab'a, Egypt', in: P. Pfälzner, H. Niehr, E. Pernicka, S. Lange, T. Köster (eds.), Contextualising grave inventories in the ancient Near East: proceedings of a workshop at the London 7th ICAANE in April 2010 and an International Symposium in Tübingen in November 2010, both organised by the Tübingen Post-Graduate School 'Symbols of the Dead', Wiesbaden 2014, pp. 120122, fig. 7; Müller, in: Miniaci, Grajetzki (eds), The world of Middle Kingdom Egypt, p. 250.

${ }^{99} C f$. burial depositions inside domestic buildings found in the town of Wah-sut at South Abydos, Picardo, N., 'Egypt's Well-to-Do. Elite Mansions in the Town of Wah-Sut', Expedition 48/2 (2007), p. 39. Infant burials were also commonly found in settlements, see excavation of Lahun town, where the floors of the chambers continuously accommodated babies buried in boxes under them Petrie, W.F.M., Kahun, Gurob, and Hawara, London 1890, 12, 24; $c f$. also Tristant, Y., 'Les enterrements d'enfants dans l'Égypte prédynastique et pharaonique', in: Nenna, M-D., (ed.), L'enfant et la mort dans l'Antiquité II. Types de tombes et traitement du corps des enfants dans l'antiquité gréco-romaine. Actes de la table ronde internationale organisée à Alexandrie, Centre d'Études Alexandrines, 12-14 novembre 2009, Alexandrie 2012, pp. 44-9; Zillhardt, R., Kinderbestattungen und die soziale Stellung des Kindes im alten Ägypten: Unter besonderer Berücksichtigung des Ostfriedhofes von Deir el-Medine (=Göttinger Miszellen, Beihefte 6), Göttingen 2009, pp. 58-70.

${ }^{100}$ Laneri N., 'A Family Affair: The Use of Intramural Funerary Chambers in Mesopotamia during the Late Third and Early Second Millennia B.C.E.', in: Residential Burial: A Multiregional Exploration. Archeological Papers of the American Anthropological Association 20/1 (2010), pp. 121-35.
} 
that this practice had been 'imported' from Near Eastern civilization. However, 'houses of the dead' remain unparalleled in the Levantine and Near East environments; the closest parallels known in Levantine area are the vaulted mud-brick chambers in the area of Jericho $^{101}$-dating to the Middle Bronze Age- and the very visible tombs in the midst of the settlement of Umm el-Marra in northern Syria -dating to the Early Bronze Age- ${ }^{102}$ Although attested only in an area exposed to external contact, eastern Delta, 'houses of the dead' have been documented only in the late Middle Kingdom strata, and surprisingly in the Hyksos Period are no longer visible in the archaeological record. Therefore, the 'house of the dead' could be described as (failed?) tentative of creation of an 'architectural' feature to reinforce social memory, possibly to sustain the construction of a mutated late Middle Kingdom household identity. As explained by Miriam Müller, in the multi-ethnic society that was Avaris in the late Middle Kingdom, a visible display of household identity grounded in the aspect of their master's social identity, had the effect of strengthening the continuity and prosperity of the household, transforming the tomb into a place of collective memory. ${ }^{103}$ One of the driving forces for the installation of the 'house of the dead' can be sought in a changed burial demography of the late Middle Kingdom. The northern region of Egypt, in close contact with external cultural flows, may have conceived a peculiar way to express such a transformation of society through the need of collective memory placed in the living areas, perhaps greatly influenced by Levantine traditions. ${ }^{104}$ The 'houses of the dead', like multiple burials, stressed close proximity to the dwellings of the living -who probably also conducted rites inside the house- and, above all, social continuity.

\section{Bodies as objects in the burial equipment}

A grave, although made by several material and immaterial constituent layers including, for instance, objects, architectural structures, funerary rituals and remembrance acts, is pragmatically intended as a place or a container for the conservation of the body. In the logic of burial assemblage, the body (as corpse/identity/accumulation of social relations) ${ }^{105}$ has been seen as the element that provides the raison d'être for the burial itself; the other elements of the burial are considered secondary additions, intended as radiating projections supporting the body-nucleus. This has created an imbalance in the logic of indexing the different constituents of the grave itself. Therefore, scholars have usually tended to dichotomise the ensemble of the grave into two broad different categories: on the one hand, is the body as the real ontological centre of the burial itself, and, on the other hand, all of the other countable objects, which were influential or created especially for shaping the mortuary ideology. Scholars have mainly focused on an etic analysis of arrangements between objects and the corpse - always imposing a vertical dependence relation type ${ }^{106}$ - but have paid little

\footnotetext{
${ }^{101}$ Van den Brink, E.C.M., Tombs and Burial Customs at Tell el-Dab'a and Their Cultural Relationship to Syria-Palestine during the Second Intermediate Period (=BÖAIK 23), Vienna 1982, p. 70; Nigro L., 'The Built Tombs on the Spring Hill and The Palace of the Lords of Jericho ('dmr rha) in the Middle Bronze Age', in: Scloen, J.D. (ed.), Exploring the Longue Durée: Essays in Honor of Lawrence E. Stager, Winona Lake 2009, pp. 361-7.

${ }_{102}$ Schwartz, G., 'Memory and its demolition: Ancestors, animals and sacrifice at Umm el-Marra, Syria', Cambridge Archaeological Journal 23/3 (2013), pp. 495-522.

103 Müller, M., 'Modelling household identity in a multi-ethnic society', Archaeological Review from Cambridge 30/1 (2015), pp. 131-41.

${ }^{104}$ Laneri, N., 'Funerary Customs and Religious Practices in the Ancient Near East', in: C. Smith (ed.), Encyclopedia of Global Archaeology, Springer 2018, p. 10.

105 Butler, J., Bodies That Matter. On The Discursive Limits of Sex, New York 1993, pp. 1-23; Sofaer, J.R., The Body as Material Culture. A Theoretical Osteoarchaeology, Cambridge 2006, pp. 1-11.

${ }^{106}$ Ekengren in: Stutz, Tarlow, Ekengren (eds.), The Oxford Handbook.
} 
attention to an insider horizontal perspective: the role of a new body entering with older bodies and of the multiple bodies among them. With the closure of the grave, all the objects in the burial, although visually and typologically separated, became part of the world of the dead, targeting a common objective to evoke social identities and images of death through memories and through the materiality of its constituents, including architecture, bodies, artefacts and rituals. ${ }^{107}$ Although constrained and invested of social relations and identity (re)-constructions, human (dead) bodies are subject to the same analytical processes of other artefacts, sharing the same materiality network, which crosses the biological boundaries between animals, artefacts, and people. ${ }^{108}$ As other 'inanimate objects', human bodies have a direct agency in shaping and transforming people's lives; ${ }^{109}$ therefore the boundaries between dead bodies and objects break down as they are mutually entangled in a complex network of relations inside the logic of burial assemblage. ${ }^{110}$ Therefore, bodies and objects in a burial are part of a common material assemblage and their materiality does not differentiate one from the other. ${ }^{111}$ The practice of sequential multiple burials reinforces the transformation of dead bodies into part of the burial equipment, subtracting centrality from the role of the body ${ }^{112}$ and disrupting the narrative tied to individual biographies. ${ }^{113}$ The passage of time increased the objectification of the body itself (in ancient as in modern times); i.e. the social context in which the body was placed slowly faded out and, with this process, also the body was losing its affective and sensorial links, increasing an 'artefactual' perception. For instance, in a multiple grave from Azraq 18 in Jordan in Neolithic contexts with Natufian traditions, complete skulls were removed from the bodies, at the times when fresh interments were being made, exactly as any other object that could have been subtracted during the reopening of the tomb. ${ }^{114}$ The individuals buried in the Mycenaean Grave Circle A, which was in use till the Late Helladic IIB (ca. 1500 BC), were monumentalised inside a sacred temenos by the later occupation of the site in the Late Helladic III (ca. $1250 \mathrm{BC}$ ). The purpose was clear: to transform the dead bodies of Circle A into symbolic objects/monuments that projected a mnemonic reference of a heroic past onto the present. ${ }^{115}$ Bodies or body parts of individuals

${ }^{107}$ Ekengren in: Stutz, Tarlow, Ekengren (eds.), The Oxford Handbook, 134.

${ }^{108}$ Sofaer, J.R., The Body as Material Culture: A Theoretical Osteoarchaeology, Cambridge 2006.

${ }^{109}$ Kopytoff, I., 'The cultural biography of things: commoditization as a process', in: Appadurai, A. (ed.), The Social Life of Things: Commodities in Cultural Perspective, Cambridge 1986, pp. 64-91; Ingold, T., 'Situating Action VI: a comment on the distinction between the material and the social', Ecological Psychology 8 (1996), pp. 183-7; Gosden, C., Marshall, Y., 'The biographical role of objects', World Archaeology 31/2 (1999), The Cultural Biography of Objects, pp. 169-78; Williams, H.M.R., 'Introduction: The archaeology of death, memory and material culture', in: ed. Williams, H.R. (ed.), Archaeologies of Remembrance: Death and Memory in Past Societies, New York 2003, pp. 1-24.

110 Jones, A., Archaeological Theory and Scientific Practice, Cambridge 2002; Latour, B., Reassembling the social: An introduction to actor-network-theory, Oxford-New York 2005; Knappett, C., 'Photographs, skeumorphs and marionettes: some thoughts on mind, agency and object', Journal of Material Culture 7/1 (2002), 97-117; Knappett, C., Network Analysis in Archaeology: New Approaches to Regional Interaction, Oxford 2013.

${ }^{111}$ Brück, J., 'Body metaphors and technologies of transformation in the English Middle and Late Bronze Age', in: Bruck, J. (ed.), Bronze Age landscapes. Tradition and transformation. Oxford 2001, pp. 149-60.; Fowler, C., The Archaeology of Personhood, London 2004.

${ }^{112}$ Crawford, S., 'Companions, co-incidences or chattels? Children and their role in early Anglo-Saxon multiple burials', in: Crawford, S., Shepherd, G. (eds.) Children, Childhood and Society. IAA Interdisciplinary Series Vol. I: Studies in Archaeology, History, Literature and Art (=BAR International Series 1696), Oxford 2007, p. 89.

${ }^{113}$ See the example of the Tullund Man, Hallam, E., Hockey, J., Howarth, G., Beyond the Body. Death and Social Identity, London 1999, pp. 91-2.

${ }^{114}$ Bocquentin, F., Garrard, A., 'Natufian collective burial practice and cranial pigmentation: A reconstruction from Azraq 18 (Jordan)' Journal of Archaeological Science: Reports 10 (2016), pp. 693-702.

115 Antonaccio, C.M., An Archaeology of Ancestors. Tomb Cult and Hero Cult in Early Greece, London 1995, pp. 49-53. 
have been since antiquity altered, adapted, restored, collected and exchanged, purely like objects, such as the relics of saints circulated in a commercialised spiritual trade in medieval and early modern times. ${ }^{116}$ The passage of the Tollund Man is particularly instructive: when in 1950, after its discovery, it was ascertained that the dead man unearthed by farmers in Tollund Fen (Denmark) had no relatives or friends remaining to recognize him, and his relics were over two thousand years old, it started to be perceived as a clinical and archaeological object. ${ }^{117}$ Therefore, the passage of time tend to elide social and affective links and to establish new symbolic values, given by the perception of the body as an object. The objectification of the human body transforms the body and its parts into a referential social value and a symbolic anchor in both time and memory. ${ }^{118}$ The assemblage of multiple bodies constitutes a 'political' 119 (since it is deliberate, but not necessarily always intentional) mnemonic selection of certain components and the segregation of others: 'a way of conceptualizing time through its materiality'. ${ }^{120}$ Since funerary activities have the specific purpose of projecting and renegotiating new (or existing) social relations onto the living community through the selection of objects disposed in the grave, ${ }^{121}$ the increase and spread on a preeminent scale of 'sequential multiple burials' in the late Middle Kingdom may mirror the need for the renegotiation of the role of the dead body within the burial assemblage and the tomb. The multiple burial becomes a memory container and dead bodies constitute the tangible mnemonic bridge to the past and social identity of the living. ${ }^{122}$

A changed burial demography at the end of the Middle Kingdom may mirror a changed structure of the social or economic context, ${ }^{123}$ which aims at emphasising more actively aspects of cohesion and continuity within a - perhaps - larger corporate group (see the increase of people named/represented on stelae). In turn, increased numbers of link inside corporate social groups may be mirrored in the altered burial demography at the end of the Middle Kingdom (see the increase of bodies in sequential multiple burials, but also the lexical changes in the vocabulary relating to the family, ${ }^{124}$ and the extended social inclusion for the term Ab.t in the Coffin Text spell 146). A renewed social structure needs to

\footnotetext{
116 Tarlow, S., Ritual, Belief and the Dead in Early Modern Britain and Ireland, New York 2011, pp. 120-30.

${ }^{117}$ Hallam, Hockey, Howarth, Beyond the Body, 91-2

${ }^{118}$ Robb, J., 'Creating death: an archaeology of dying', in: Stutz, L.N., Tarlow, S., Ekengren, F. (eds.), The Oxford Handbook of the Archaeology of Death and Burial, Oxford 2013, pp. 441-458. .

119 Scheper-Hughes, N., Lock, M.M., 'The mindful body: A prolegomenon to future work in medical anthropology', Medical Anthropology Quarterly 1/1 (1987), pp. 6-41; Duncan, W.N., Schwarz, K.R., 'Partible, Permeable, and Relational Bodies in a Maya Mass Grave', in: Osterholtz, A.J., Baustian, K.M., Martin, D.L. (eds.), Commingled and Disarticulated Human Remains: Working Toward Improved Theory, Method, and Data, New York-Heidelberg-Dordrecht-London 2014, 149-70.

${ }^{120}$ Hamilakis, Y., 'Sensorial Assemblages: Affect, Memory and Temporality in Assemblage Thinking', CAJ 27/1 (2017), pp. 169-82.

${ }^{121}$ Fowler, C., 'Identities in Transformation: Identities, Funerary Rites, and the Mortuary Process', in: Stutz, L.N., Tarlow, S., Ekengren, F. (eds.), The Oxford Handbook of the Archaeology of Death and Burial, Oxford 2013, pp. 511-26; cf. Ucko, P., 'Ethnography and archaeological interpretation of funerary remains', World Archaeology 1/2 (1996), pp. 262-80.

122 Oestigaard, T., Goldhahan, J., 'From the Dead to the Living. Death as Transactions and Renegotiations', Norwegian Archaeological Review 39/1 (2006), pp. 27-48. See also for Near East: Laneri, N., 'Locating the social memory of the ancestors. Residential funerary chambers locales of social remembrance in Mesopotamia during the late third and early second millennia BC', in: P. Pfälzner, H. Niehr, E. Pernicka, S. Lange, T. Koster (eds), Contextualizing grave inventories in the ancient Near East. Proceedings of the workshop at the London $7 t$ h ICAANE in April 2010 and an International Symposiumin Tubingen in November 2010, both organized by the Tubingen Post-graduate school 'Symbols of the dead', Qatna Studien Supplementa, vol. III, Berlin, pp. 3-11. ${ }^{123} \mathrm{Cf}$. Cauwe, N., 'Skeleton in motion, ancestors in action: Early Mesolithic collective tombs in southern Belgium', Cambridge Archaeological Journal 11/2 (2001), pp. 147-163; Kesnawi, P., Mortuary ritual and society in Bronze Age Cyprus, London 2004.

${ }^{124}$ Franke, Altägyptische Verwandtschaftsbezeichnungen. pp. 289-301.
} 
renegotiate its material bridges with the symbols of its identity: this is not only visible in the change and transformation of the objects in the funerary equipment ${ }^{125}$ but also in the number of people involved in one of the symbolic places of collective memory, the tomb, which brings a living community in close contact with the dead. Strategies of social memory may change across the time. For instance, hundreds of Old Kingdom graffiti found at Elkab ${ }^{126}$ record the identity of influential local officials through genealogical sequences going back up to six generations, testifying in favour of an ideology of local power grounded on familiar and lineage mechanisms. However, such a strategy does not find an echo in a parallel funerary programme, since decorated tombs belonging to the Old Kingdom officials of Elkab are rather rare or little known at the present. ${ }^{127}$ In the late Middle Kingdom, the channels of communication changed (see the interruption in the custom of the letters to the dead and the attempt at establishing an uncommon type of architecture, the house of the dead, in the Delta), directing their focus also towards the funerary activity. The tomb is the ideal memory container, ${ }^{128}$ and dead bodies constitute the tangible mnemonic bridge to the past and social identity. Therefore, older bodies, above all those belonging to recently dead individuals, became one of the essential parts of the burial equipment communicative programme, transforming in turn the nature of the tomb itself. In the light of a changed burial demography, the presence of older bodies may have influenced the selection of the range of objects to be deposited inside the burial. In fact, at the end of Middle Kingdom a consistent infiltration of the domestic sphere inside the funerary domain is clearly visible: iconography and artefacts gathered from domestic contexts started to replace or juxtapose those objects produced exclusively for burial. ${ }^{129}$ Therefore, instead of counting only objects when describing changes in funerary customs, we should start counting objects and bodies together.

\section{Captions:}

Fig. 01 Plan of the tombs T 130 and T 131 from the cemetery M. X of Mirgissa, from Vercoutter, J. ,Mirgissa II: les nécropoles (=Mission archéologique française au Soudan), Paris 1975, figs. 77 and 80.

Fig. 02 = Plan of the burial chambers of Neferkhewet and his family, from Hayes, W.C., 'The tomb of Nefer-Khewet and His Family', BMMA 30 (1935), fig. 1.

Fig. 03 = Stela of Khonsu from Abydos, Thirteenth Dynasty; Wien ÄS 180, from Hein, I., Satzinger, H., Stelen des Mittleren Reiches: Einschliesslich der I. und II. Zwischenzeit. Vol. 2 (=CAA, Kunsthistorisches Museum, Wien 7), Mainz am Rhein 1993, pp. 103-11.

Fig. 04 = Late Middle Kingdom rectangular slab, MMA 65.120.2 @ License under Creative Common.

Fig. 05 = Schematic representation of estate 1, stratum b/2 (@ Bietak, Eigner) from Müller, M., 'New approaches to the study of households in Middle Kingdom and Second Intermediate Period Egypt', in: Miniaci, G., Grajetzki, W. (eds), The world of Middle

\footnotetext{
${ }^{125}$ Miniaci, G., 'The collapse of faience figurine production at the end of the Middle Kingdom: reading the history of an epoch between postmodernism and grand narrative', Journal of Egyptian History 7 (1), pp. 109-42

${ }^{126}$ Vandekerckhove, H. and Müller-Wollermann, R., Elkab VI. Die Felsinschriften des Wadi Hilâl, Bruxelles 2001.

${ }^{127}$ Moreno García, in: Fitzenreiter and Herb (eds.), Dekorierte Grabanlagen, p. 227.

${ }^{128}$ Moreno García, in: Fitzenreiter, Herb (eds.), Dekorierte Grabanlagen, pp. 215-42.

${ }^{129}$ Cf. Grajetzki, Tomb treasures, pp. 156-67; Quirke, S., Exploring religion in ancient Egypt, Chichester, Malden, MA 2015, p. 213; Quirke, Birth tusks; Miniaci, G., 'Unbroken stories: Middle Kingdom faience figurines in their archaeological context', in: Miniaci, G., Betrò, M., Quirke, S. (eds). Company of Images. Modelling the ancient imaginary world of the Middle Kingdom. Proceedings of the international conference held on 18th-20th September in London, UCL, OLA 262, Leuven 2017, pp. 235-84.
} 
Kingdom Egypt (2000 - 1550 BC). Contributions on archaeology, art, religion, and written sources (=MKS 1), vol. I, London 2015, fig. 10. 